\title{
Rationale for the surgical treatment of pulmonary metastases
}

\author{
PETER MARKS, MOHAMED Z FERRAG, HASHMAT ASHRAF \\ From the Thoracic Unit, Westminster Hospital, London
}

ABSTRACT In a twenty-six year period, 90 patients underwent surgical treatment for metastatic malignant disease of the lung. The primary tumour had apparently been completely removed and there was no evidence of other metastatic spread. Thirty patients enjoyed a survival of more than five years. In 22 cases the lung lesion was multiple and in 17, the lesions were bilateral. In patients with pulmonary metastases, but without evidence of other dissemination of the disease, resection of the lesions provided useful palliation, and $33 \%$ survived for five years or more.

Prolonged survival and cure of patients after the surgical removal of pulmonary metastatic lesions seems well established. Ochsner and associates ${ }^{1}$ credited Divis ${ }^{2}$ with performing the first successful resection of a metastatic tumour in the lung. However, the stimulus for surgical efforts to cure patients with pulmonary metastases was provided by the report of Barney and Churchill ${ }^{3}$ in 1939. Their patient whose primary lesion was an adenocarcinoma of the kidney, lived 23 years after wedge excision of a solitary pulmonary metastatic tumour. Several reviews of the surgical problem have been published, but the determination of survival statistics has been hampered by a lack of long-term follow-up on a large group of patients.

We decided to investigate the long-term survival of 90 patients with pulmonary metastases who were operated on at Westminster Hospital between 1945 and 1971.

\section{Patients and methods}

Ninety patients with pulmonary metastases underwent surgical treatment in the Thoracic Unit of Westminster Hospital between 1945 and the end of 1971.

Forty-seven $(52 \%)$ of the patients had metastatic carcinomas, $37(41 \%)$ had metastatic sarcomas, and six $(7 \%)$ had metastatic tumours of embryonal origin. In $22(24 \%)$ the lesions were multiple and in $17(19 \%)$ cases they were bilateral.

There were 26 metastases in the right upper

Address for reprint requests: Peter Marks, Lecturer in Medicine, King's College Hospital, Denmark Hill, London, SE5 9RS. lobe, 38 in the right lower lobe and 16 in the middle lobe. In the left lung, 29 metastases were in the upper and 32 in the lower lobe. No lesion was at the apex of the lung. Bilateral metastases were present in 17 patients. In 43 patients only the right lung was involved, and in 30 patients only the left lung. The sizes of the deposits varied between being just visible on a chest radiograph, to $5 \mathrm{~cm}$ in diameter.

One of the criteria for inclusion within the study is that the histology of the primary and secondary lesions should agree. In squamous carcinoma this must be debatable, since the histological differentiation between secondary lesions and new primary disease is difficult.

Although secondary tumours are said to be symptomless, in our experience this was not so. As the tumours grew they were prone to persistent infection causing significant malaise. The incidence of different symptoms with secondary tumours is set out in table 1 ; it was noticeable how patients who had their secondary deposits removed had a very real improvement in quality of life.

The extent of operation varied from simple wedge resection to wedge resection and contro-

Table 1 Incidence of different symptoms with secondary tumours

\begin{tabular}{lc}
\hline Symptoms & Number of patients \\
\hline Malaise & 31 \\
Dyspnoea & 18 \\
Sputum production, fever & 18 \\
Pain & 7 \\
Haemoptysis & 2 \\
Asymptomatic & 14
\end{tabular}


lateral pneumonectomy (table 2). The latent period was defined as the number of years between the treatment of the primary and treatment of the secondary deposit. All patients included within the study were followed at three monthly intervals for at least five years and routine chest radiographs were obtained at each outpatient appointment.

\section{Results}

The number of patients in each five-year period is set out in table 3 . In 86 patients, surgical removal of metastatic tumour was possible while four were inoperable. The operative mortality was $7 \%$. The figure shows the survival plotted against years since the operation; the five-year survival was $33 \%$. Patients who had a recurrence of their pulmonary disease and required a further thoracotomy sometimes had very long survivals nevertheless. Thus, of 29 patients in this group, seven (24\%) survived five years. The symptoms of secondary tumours are set out in table 1 . In over $90 \%$ of cases disappearance of symptoms or a worthwhile palliation was achieved.

The effects of size of secondary lesion, latent period, known duration of metastases, and chest wall involvement on survival have all been investigated (table 4). There was no evidence of any relationship between survival and either latent period or the known duration of metastases, but

Table 2 Surgical procedures

\begin{tabular}{lrl}
\hline Procedure & Cases & Operative deaths \\
\hline $\begin{array}{l}\text { Pneumonectomy and wedge } \\
\text { resection }\end{array}$ & 3 & 0 \\
$\begin{array}{l}\text { Pneumonectomy } \\
\text { Multiple lobectomy and wedge }\end{array}$ & 13 & 5 \\
$\quad$ resection & 3 & 0 \\
Multiple lobectomy & 4 & 1 \\
Single lobectomy and wedge & 9 & 0 \\
$\quad$ resection & 34 & 0 \\
Single lobectomy & 10 & 0 \\
Multiple wedge resection & 10 & 0 \\
Single wedge resection & 4 & 0 \\
Biopsy only & 90 & 6 \\
Total &
\end{tabular}

Table 3 Number of patients who had operations in each five-year period

\begin{tabular}{ll}
\hline Five-year period & Number of patients \\
\hline $1945-49$ & 16 \\
$1950-54$ & 18 \\
$1955-60$ & 12 \\
$1961-64$ & 15 \\
$1965-69$ & 27 \\
$1970-71$ & 2 \\
Total & 90 \\
\hline
\end{tabular}

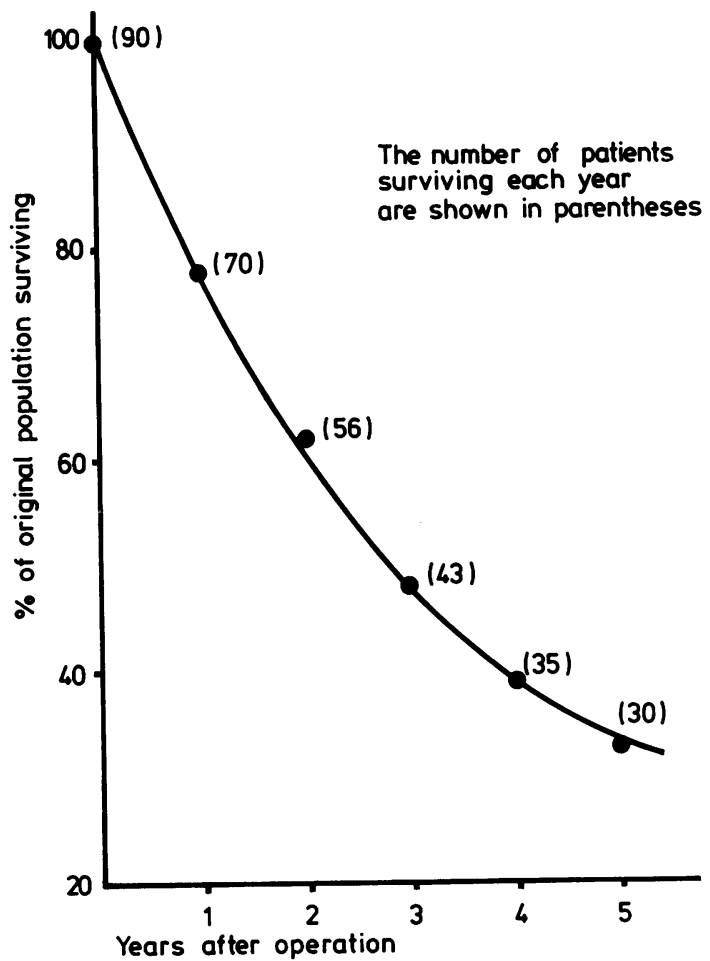

Figure Percentage of original population surviving each postoperative year.

Table 4 Five-year survival and patient characteristics

\begin{tabular}{|c|c|c|c|c|}
\hline (a) & $\begin{array}{l}\text { Size of } \\
\text { metastasis* } \\
(\mathrm{cm})\end{array}$ & $\begin{array}{l}\text { Number of } \\
\text { secondaries } \\
\text { per patient }\end{array}$ & $\begin{array}{l}\text { Five-year } \\
\text { survival }\end{array}$ & Percentage \\
\hline & $\begin{array}{l}<1 \\
1-3 \\
3-5 \\
>5\end{array}$ & $\begin{array}{l}2 \cdot 2 \\
1 \cdot 4 \\
1 \cdot 4 \\
1.8\end{array}$ & $\begin{array}{r}5 / 13 \\
13 / 33 \\
10 / 34 \\
2 / 10\end{array}$ & $\begin{array}{l}38 \\
39 \\
29 \\
20\end{array}$ \\
\hline (b) & $\begin{array}{l}\text { Latent period } \\
\text { (yr) } \\
1 \\
2-4 \\
4\end{array}$ & $\begin{array}{l}\text { Five-year } \\
\text { survival } \\
10 / 31 \\
13 / 39 \\
7 / 20\end{array}$ & $\begin{array}{l}\text { Percentage } \\
32 \\
33 \\
35\end{array}$ & \\
\hline (c) & $\begin{array}{l}\text { Duration of } \\
\text { metastasis } \\
(y r) \\
1 \\
2-4 \\
4\end{array}$ & $\begin{array}{c}\text { Five-year } \\
\text { survival } \\
\\
17 / 52 \\
10 / 29 \\
3 / 9\end{array}$ & $\begin{array}{l}\text { Percentage } \\
33 \\
34 \\
33\end{array}$ & \\
\hline (d) & $\begin{array}{l}\text { Chest wall } \\
\text { involvement } \\
8 \text { with } \\
82 \text { without }\end{array}$ & $\begin{array}{c}\text { Five-year } \\
\text { survival } \\
1 / 8 \\
29 / 82\end{array}$ & $\begin{array}{l}\text { Percentage } \\
12 \\
35\end{array}$ & \\
\hline
\end{tabular}

*Size is defined as the size of the largest lesion when there are multiple $\varrho$ lesions.

There was no significant difference between the groups. 
there was poorer survival both with increasing size of the secondary lesion (table 4 (a)) and with chest wall involvement (table 4 (d)), but there were insufficient patients to establish that these were real effects.

Table 5 shows the cases classified by the primary lesion. The five-year survival rates were very similar for the carcinoma, sarcoma, and embryonal cell groups, $34 \%, 32 \%$, and $33 \%$ respectively. It is of interest that out of seven patients with adenocarcinoma of the kidney there were three $(43 \%)$ who survived for five years after resection of the secondary tumour.

Table 5 Cases classified by primary lesion

\begin{tabular}{lrl}
\hline Primary lesion & & $\begin{array}{l}\text { Number of five-year } \\
\text { survivors }\end{array}$ \\
\hline Carcinoma total & 47 & 16 \\
Corpus uteri & 2 & 1 \\
Cervix uteri & 1 & 0 \\
Large bowel & 17 & 7 \\
Breast & 10 & 4 \\
Kidney & 7 & 3 \\
Ovary & 1 & 0 \\
Mouth and larynx & 1 & 0 \\
Stomach & 1 & 0 \\
Bladder & 4 & 1 \\
Parotid & 1 & 0 \\
Melanoma & 1 & 0 \\
Tongue & 1 & 0 \\
Sarcoma total & 37 & 12 \\
Osteogenic & 24 & 8 \\
Fibromatous & 4 & 1 \\
Synovial & 3 & 1 \\
Chondromatous & 1 & 0 \\
Leiomyomatous & 1 & 1 \\
Reticulum cell & 2 & 0 \\
Hystiocytic & 1 & 0 \\
Hodgkins & 1 & 1 \\
Embryonal cell total & 6 & 2 \\
Teratoma testis & 4 & 1 \\
Nephroblastoma & 2 & 1 \\
\hline
\end{tabular}

\section{Discussion}

In 1965 Thomford, et al $^{4}$ published the report of a series of 221 operations for the attempted cure of metastatic tumours of the lung. The overall "cure" rate was $30.3 \%$ for five years. Their conclusion was that palliative pulmonary resection for metastatic pulmonary lesions seemed justifiable on the basis of prolongation of life and the degree of comfort afforded to the patient. Drew ${ }^{5}$ in 1961, concluded that surgery was justifiable and reported several long survivors. He stated that the removal of a solitary metastasis was governed by the same criteria which guide the surgical treatment of primary lung cancer. Thus provided that the necessary lung resection can be tolerated by the patient, operation is worthwhile. He also described successful resection for multiple metastases. Further study of the series of Holmes Sellors ${ }^{6}$ and Rees and Cleland ${ }^{7}$ leads to the conclusion that surgical excision of a solitary metastatic malignant lesion of the lung is of benefit in cases in which the primary tumour apparently has been completely removed and in which there is no evidence of metastatic spread.

Our results show that resection for metastatic malignant lesions in the lung gave a $33 \%$ five-year survival rate. Also, palliation of distressing pulmonary symptoms, set out in table 1 , was achieved in over $90 \%$ of cases.

The distribution of pulmonary metastases merits further note. In those cases in which there were bilateral metastases, those on the right side of the lung were both larger and more prolific than on the left side. Seiler ${ }^{8}$ did not discuss the site of the lesion in the cases which he analysed, but in 10 case histories given in detail, the right lung was involved eight times and the left only on two occasions. Primary cancer of the lung is slightly more common on the right side than on the left, but this can be explained by the equally slight difference in bulk between the two organs. The inequality in blood flow, $55: 45$, is not the complete explanation, which must remain obscure.

In addition, of our 90 patients, no single lesions was present at the apex of either lung. West ${ }^{9}$ reports that there is a steady fall in blood flow per unit volume with rib number and, therefore distance from the bottom to the top of the lung, and that flow is almost nil at the apex.

Extensive surgery appears to be contraindicated in that five of the six hospital deaths followed pneumonectomy. However, multiple and bilateral operations do not produce a greater mortality and survival is as good as that after operation for a single lesion. The length of the latent period does not affect the outcome. ${ }^{7}$ The known duration of the secondary deposit also does not affect fiveyear survival, but chest wall involvement is associated with a bad prognosis.

We would like to thank $\mathrm{Mr} \mathrm{C}$ Drew and $\mathrm{Mr} \mathrm{P}$ James for allowing us to use clinical material, $\mathbf{M r} \mathbf{J}$ Bailey for invaluable help, and Mrs J Smith for the use of her meticulous records.

\section{References}

1 Ochsner A, Clemmons EF, Mitchell, WTJr. The treatment of metastatic pulmonary malignant disease. Journal Lancet 1976;83:16-20.

2 Divis G. Ein Beitrag zur operativen Behandlung der lungengeschwulste. Acta Chir Scand 1927;62:329-41 
${ }^{3}$ Barney JD, Churchill EJ. Adenocarcinoma of the kidney with metastasis to the lung cured by nephrectomy and lobectomy. J. Urol 1939;42:269-76.

4 Thomford NR, Woolner, LB, Clagett OT. The surgical treatment of metastatic tumors of the lungs. $J$ Thorac Cardiovasc Surg 1965;49:357-70.

${ }^{5}$ Drew CD. Pulmonary resection for metastases. In: Smith R, ed. Progress in Clinical Surgery. London: Churchill, $1961: 310-21$.
- Sellors TH. Treatment of isolated pulmonary metastases. Br Med J 1970;2:253-6.

7 Rees GM, Cleland WP. Surgical treatment of pulmonary metastases. Thorax 1972;27:654-6.

${ }^{8}$ Seiler HH, Claggett OT, MacDonald JR. Surgery of pulmonary metastases. Thorac Surg. 1950;19:655-75.

${ }^{9}$ West JB. Pulmonary resection for metastatic lesions. In: Ventilation/blood flow and gas exchange. Oxford: Blackwell Scientific Publications, 1977:17. 